\title{
Investigating Reading Comprehension Problems Encountered by Sudanese Secondary School Students: Teachers Perspective
}

\author{
Dr. Khaled Hassan Ali Eltayb
}

\author{
Assistant Professor \\ Omdurman Ahlia University -College of Arts- ESP Unit \\ Omdurman, Sudan \\ khaledkenana66@yahoo.com
}

\begin{abstract}
This study aimed to investigate reading comprehension problems encountered by Sudanese EFL secondary school students. To achieve the purpose of the study, the researcher used an analytical descriptive method and a questionnaire as a tool. The sample of the study consisted of 30 teachers who were randomly selected from Kenana secondary schools in White Nile State, and responded to the items of the questionnaire. The findings of the study showed that Sudanese Secondary School students face problems in reading and answering comprehension questions. The main causes of these problems were attributed to students' lack of vocabulary and motivation. English language curriculum and lack of teachers' training were also considered as causes of this difficulty. The researcher suggested some recommendations for both teachers and syllabus designers. As a recommendation for both sides; teachers and students, the researcher recommended that English language teachers should be trained to improve students' levels in reading comprehension. Teachers should also motivate their students to have more interest in learning English language. In addition to that, they should encourage their students to read extensively so as to improve their level of comprehension,
\end{abstract}


and syllabus designers should provide good reading material with adequate exercises besides English language literature.

Keywords: Reading Comprehension- Secondary Schools - Curriculum - Syllabus Designers Introduction

English language undoubtedly, is the most widely spread language in the world. In recent years, there has been great interest in learning English in many countries all over the world, this interest has been increased for many reasons; firstly, is being the language of modern science and technology and a means of study in English native speaking countries and a job requirement. Reading is an important skill in any English language learning: it supports the development of overall proficiency and provides access to crucial information at work and school. With English being the dominant language of the internet, international business, and academia (including science), beginner and advanced students alike faced great problems to develop their second language reading abilities. Therefore a more emphasis has been given to reading, especially, in a foreign language context. Dechant \& Emerald (1991:1) pointed out that "reading has received more than the other aspects of education, so there is small wonder that instruction in the early grades is organized around learning to read".

Alderson (1984: 1) also assured that "reading knowledge of a foreign language is essential to academic studies, professional success and personal development”.

The present study aims to identify the different types of reading problems encountered by Sudanese Secondary School pupils and factors contributing to these difficulties and personal solutions.

Statement of the Problem

Generally, reading is a challenging skill because it involves a number of sub-skills. As Pamela and William(1986:20) pointed out "reading needs practice and integration of skills". 
Reading skill is also a complicated process that needs knowing grammatical structure and rich vocabulary.

Francoise (2000:5) stated that "the reasons why people have basic skills problems are: absence from school, sickness, unsettled home life or family problems, poor teaching, undiagnosed visual/ hearing impairment, and intergenerational effect". The researcher from his experience observed that EFL learners face a number of reading difficulties, and these difficulties could be due to a number of reasons; transfer of L1 knowledge into L2, reading word by word, and relying too heavily on their visual information. This affects their reading speed and impedes their ways to read. So they concentrate on every word. This also may have a bad effect on their ability to comprehend a passage. Thus, Kenana Secondary Schools students face some problems in understanding reading comprehension passages.

Significance of the Study

This study is an attempt to draw teachers' attention to the main reasons that affect students' achievement in reading comprehension passages. This study is expected to help teachers to find some clues and enrich them with data to solve some of the reading comprehension problems at secondary level. It is also significant in helping syllabus designers to check what students practically face when reading English language. Thus, helping the syllabus designers to tailor attractive, useful, and interesting textbooks which can stimulate learners' abilities for more knowledge. In addition to that, this study is expected to help teachers and students with useful ideas which may help them in their teaching and learning endeavor.

Objectives of the Study

The study aims to achieve the following objectives:

To identify the problems of reading comprehension passages encountered by Sudanese Secondary School Students. 
To find out the causes of those problems.

To suggest some solutions to overcome those problems.

Research Questions

This study attempts to answer the following questions

What are the problems of reading comprehension passages encountered by Sudanese Secondary School Students?

What are the causes of reading comprehension problems encountered by Sudanese Secondary School Students?

What can be done to overcome those problems?

Hypotheses of the Study

There are some problems that face Sudanese Secondary School students in reading and answering comprehension questions. It could be less attention given reading comprehension, large classes and lack of grammar knowledge cause reading problems.

$>$ The main sources of reading comprehension problems could be: Students lack of vocabulary and teaching methods.

$>$ Using short stories as supplementary material for enhancing student's motivation and developing vocabulary can help to solve these problems.

Methodology

In order to achieve the objectives of this study, the researcher designed a questionnaire and administered to secondary school teachers which focuses on investigating reading comprehension problems and how to overcome them.

The Population of the Study

The population of this study is thirty Sudanese secondary school English language teachers in the locality of Kenana in White Nile State. Their teaching experiences ranged 
from 1 to 15 years. $56.7 \%$ of them had Bachelor degree, $43.3 \%$ held masters. In order to administer the questionnaire, the researcher visited them in their offices and asked them to kindly respond to it.

Data Analysis \& Discussion

Teachers' Responses to the Questionnaire

Table (4.1) Reading comprehension problems

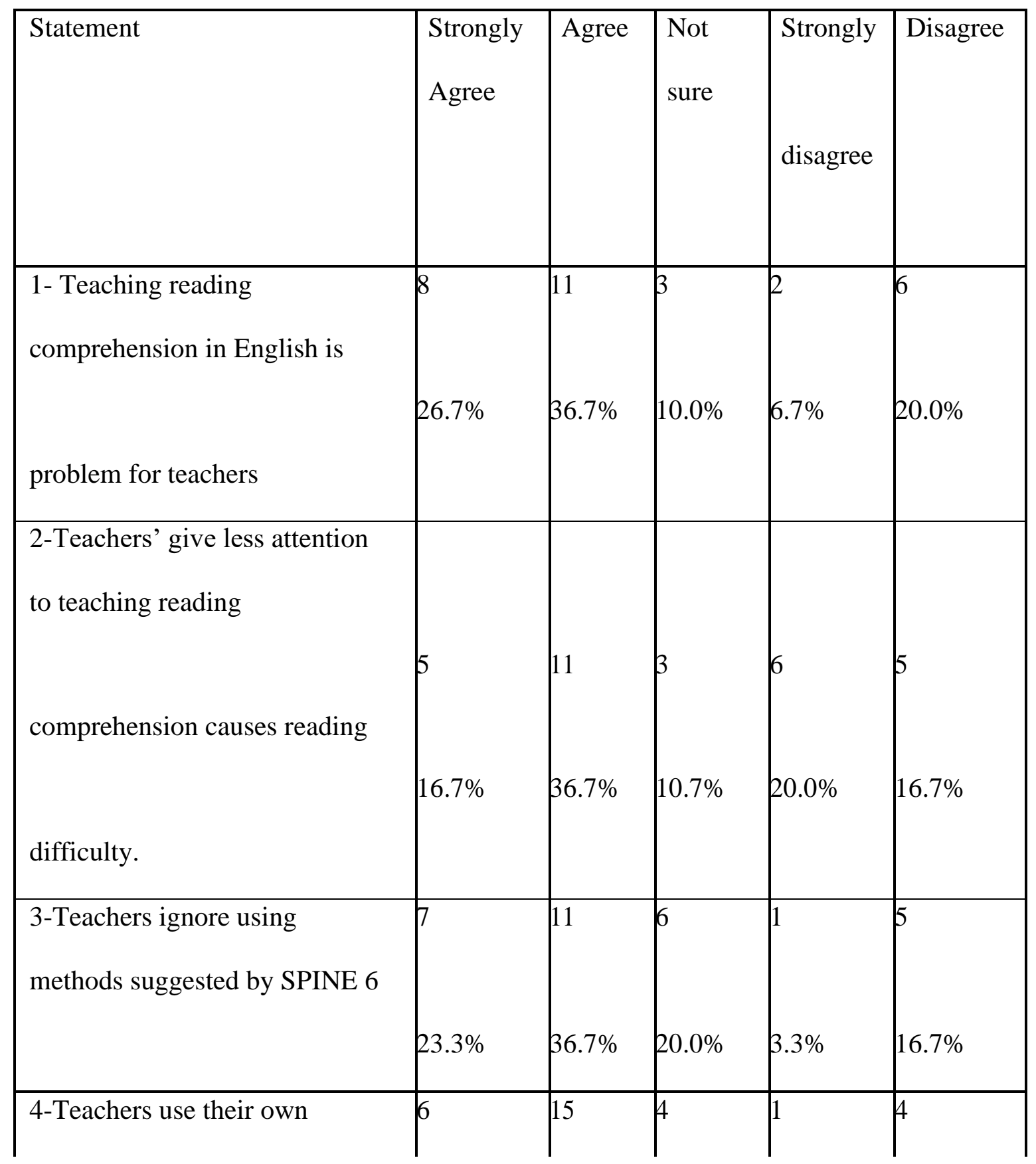




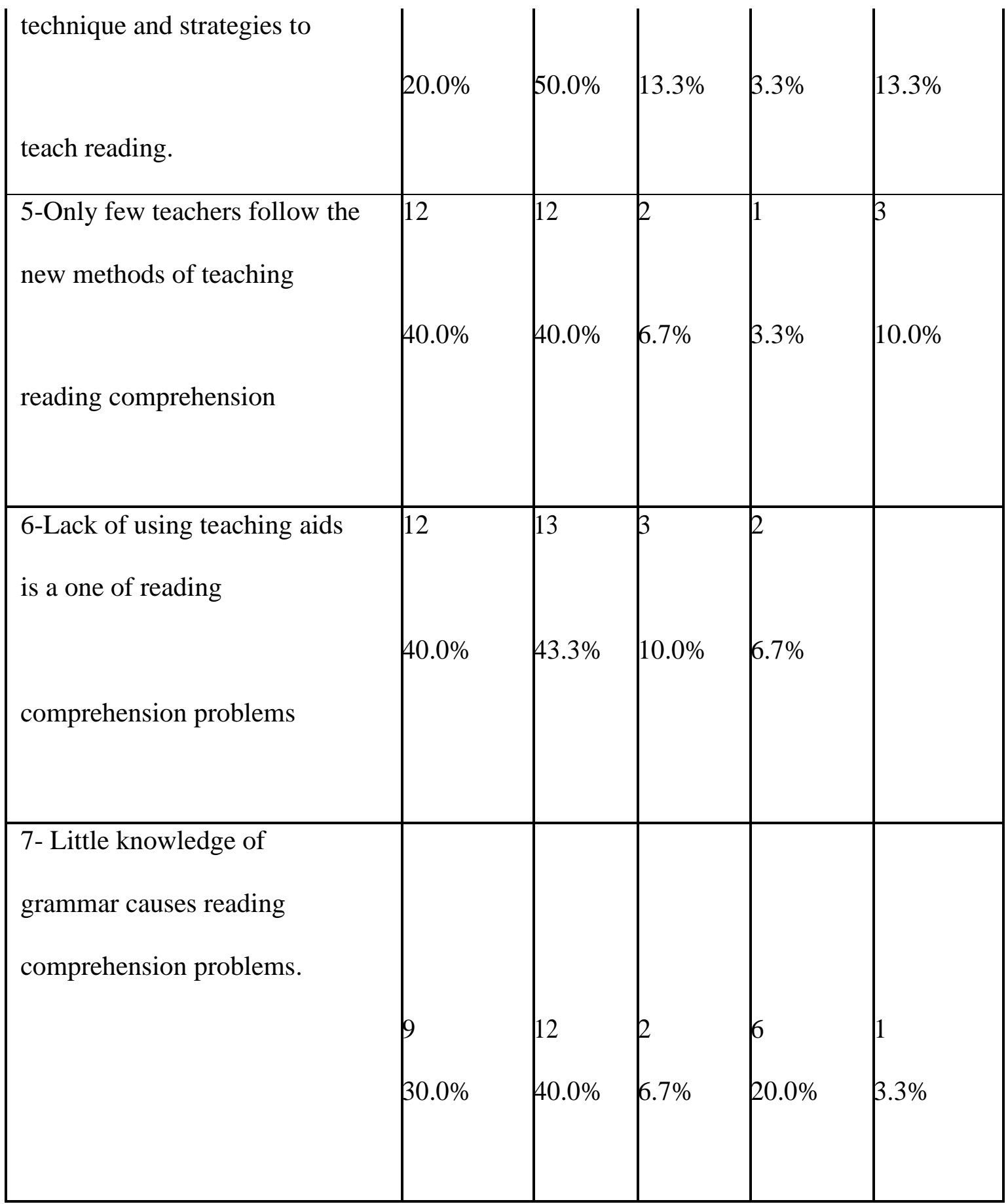

Table (4.1) shows (37\%) of the participants agreed that teaching reading comprehension in English is a problem. (26\%) of the subject strongly agreed with the point while (20\%) disagreed. Only a small number (10\%) of the participants were not sure. More than one-third $(36.7 \%)$ of the subject agreed that teachers give less attention to reading comprehension. The same number of the respondents did not believe so. More than one-third of respondents 
(37\%) agreed that teachers ignore using the methods suggested by SPINE6 whereas $23 \%$ of them strongly agreed that teachers ignore suggested methods.

(20\%) of the respondents disagreed with this idea. Only a small number (16\%) strongly agreed whereas the same number strongly disagreed, about one-quarter (23\%) strongly agreed about that (20\%) of the responders reminded not sure. (40\%) of participants agreed that only a few teachers follow the new methods of teaching reading comprehension, the same number of the teachers strongly agreed with this idea, whereas a small number $(10 \%)$ disagreed with this statement. More than one-third of the sample (43.3\%) agreed that lack of using teaching aids is one of the reading comprehension difficulties. (40\%) of the responders strongly agreed about the statement. While a small number of participants (13\%) strongly disagreed about this idea, whereas only a few of the teachers $(6.7 \%)$ strongly agreed with that point (40) of responders agreed that lack of grammar structure caused reading comprehension difficulties. About one-third (30\%) strongly agreed on that point.(20\%) of the responders disagreed with this idea. On the other hand, a few of teachers were (7\%) still not sure to vote. Table (4-2) What are the main sources of reading difficulties?

\begin{tabular}{|c|c|c|c|c|c|}
\hline Statement & $\begin{array}{l}\text { Strongly } \\
\text { Agree }\end{array}$ & Agree & $\begin{array}{l}\text { Not } \\
\text { sure }\end{array}$ & $\begin{array}{l}\text { Strongly } \\
\text { disagree }\end{array}$ & Disagree \\
\hline $\begin{array}{l}\text { 8-Lack of using } \text { Good } \\
\text { teaching methods are The }\end{array}$ & $\begin{array}{l}11 \\
36.7 \%\end{array}$ & $\begin{array}{l}13 \\
47.3 \%\end{array}$ & $\begin{array}{l}4 \\
13.3 \%\end{array}$ & $\begin{array}{l}2 \\
6.7 \%\end{array}$ & \\
\hline $\begin{array}{l}\text { main reasons Of Reading } \\
\text { comprehension problems }\end{array}$ & & & & & \\
\hline
\end{tabular}




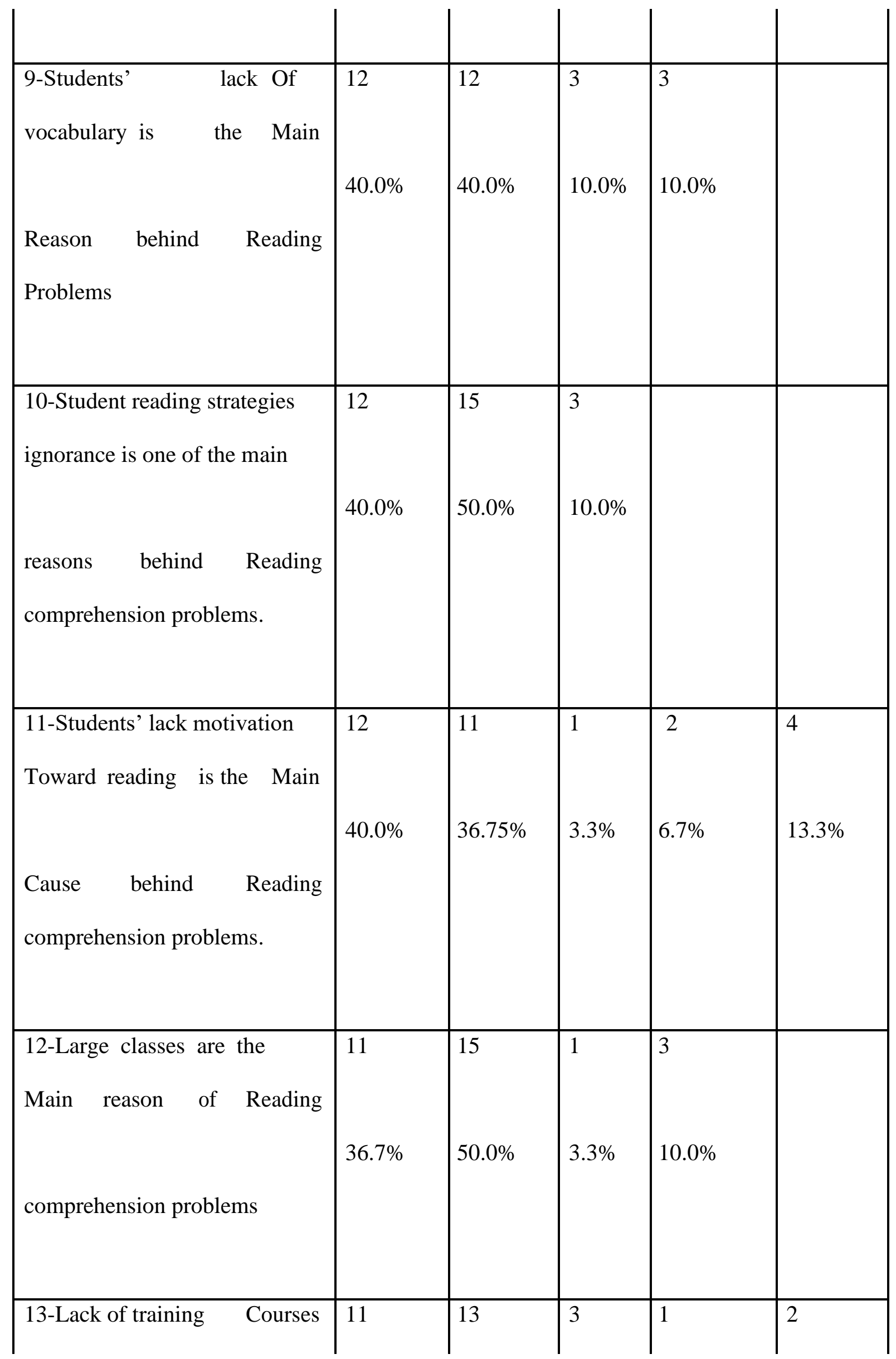




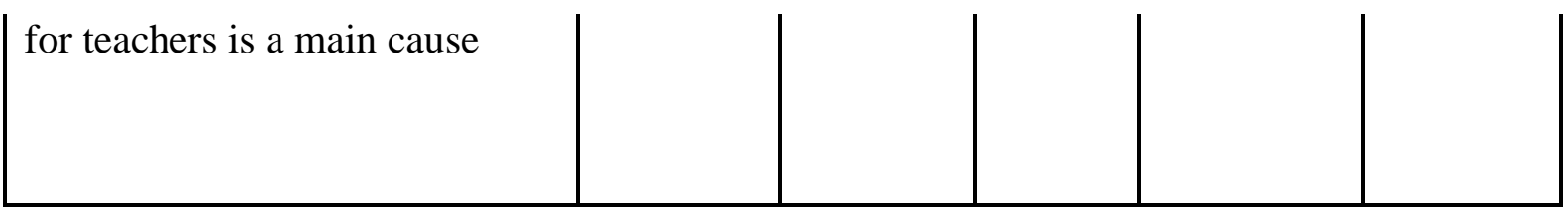

\begin{tabular}{|l|l|l|l|l|l|}
\hline of reading comprehension & $36.7 \%$ & $43.3 \%$ & $10.0 \%$ & $3.3 \%$ & $6.7 \%$ \\
problems. & & & & & \\
\end{tabular}

Table (4.4) shows that (47.3\%) of the responders agreed that lack of using good teaching methods is the main reason for reading comprehension difficulties. More than one-third $(36 \%)$ of the responders strongly agreed about this point. While a small number of them $(13 \%)$ reminded not sure, $(6 \%)$ of responders strongly disagreed with this point. (40\%) of responders agreed with the point that students' lack of vocabulary is the main reason behind reading comprehension difficulties. The same number of respondents strongly agreed with this point. Whereas the same number (40\%) of participants strongly agreed about this point. Only a small number of responders (10\%) strongly disagreed with this point whereas the same number remained not sure. Half of the respondents (50\%) agreed that students' ignorance of reading comprehension skill is one of the main reason behind these difficulties. (40\%) of the participants strongly agreed with this point. Only(10\%) of the responders remained not sure, and the same number of the respondents (10\%) strongly disagreed with that point. About half of the respondents (40\%) strongly agreed that students' lack of motivation to word reading comprehension is one of the main causes of reading comprehension difficulties. One-quarter $(27 \%)$ of the responders strongly agreed about that idea, while a small number $(16 \%)$ of the responders remained not sure while $(10 \%)$ of them strongly disagreed with that point half $(50 \%)$ of responders agreed that larger classes is the main reason of reading comprehension difficulties, more than one-third (37\%) of the responders strongly agreed with this idea, whereas a small number (10\%) ofresponders strongly disagreed with this idea more than one-third (37\%) of the responders strongly agreed 
that lack of training courses for the teachers is the main cause of reading comprehension difficulties, $(44 \%)$ of the responders agreed with the point, a small number $(10 \%)$ of responders remained not sure, whereas $(7 \%)$ of them strongly disagreed with this idea. One of the respondents strongly disagreed with lack of training courses for teachers is the minor cause of reading comprehension difficulties.

Table (4-3) Solving Reading Comprehension Problems

\begin{tabular}{|c|c|c|c|c|c|}
\hline Statement & $\begin{array}{l}\text { Strongly } \\
\text { Agree }\end{array}$ & Agree & $\begin{array}{l}\text { Not } \\
\text { Sure }\end{array}$ & $\begin{array}{l}\text { Strongly } \\
\text { Disagree }\end{array}$ & Disagree \\
\hline $\begin{array}{l}\text { 1-Supporting texts with } \\
\text { pictures, shapes, flash card, } \\
\text { puppets, can help students } \\
\text { to overcome these } \\
\text { problems. }\end{array}$ & $\begin{array}{l}14 \\
46.7 \%\end{array}$ & $\begin{array}{l}13 \\
43.3 \%\end{array}$ & $\begin{array}{l}2 \\
6.7 \%\end{array}$ & $\begin{array}{l}1 \\
3.3 \%\end{array}$ & \\
\hline $\begin{array}{l}\text { 2- Frequent training of } \\
\text { teachers can help to } \\
\text { overcome reading } \\
\text { comprehension problems. }\end{array}$ & $\begin{array}{l}11 \\
36.7 \%\end{array}$ & $\begin{array}{l}15 \\
50.0 \%\end{array}$ & $\begin{array}{l}2 \\
6.7 \%\end{array}$ & $\begin{array}{l}2 \\
6.7 \%\end{array}$ & \\
\hline $\begin{array}{l}\text { 3-Using supplementary } \\
\text { reading materials beside } \\
\text { the main reading text can } \\
\text { enhance students' }\end{array}$ & $\begin{array}{l}11 \\
36.7 \%\end{array}$ & $\begin{array}{l}15 \\
50.0 \%\end{array}$ & $\begin{array}{l}1 \\
3.3 \%\end{array}$ & $\begin{array}{l}3 \\
10.0 \%\end{array}$ & \\
\hline
\end{tabular}




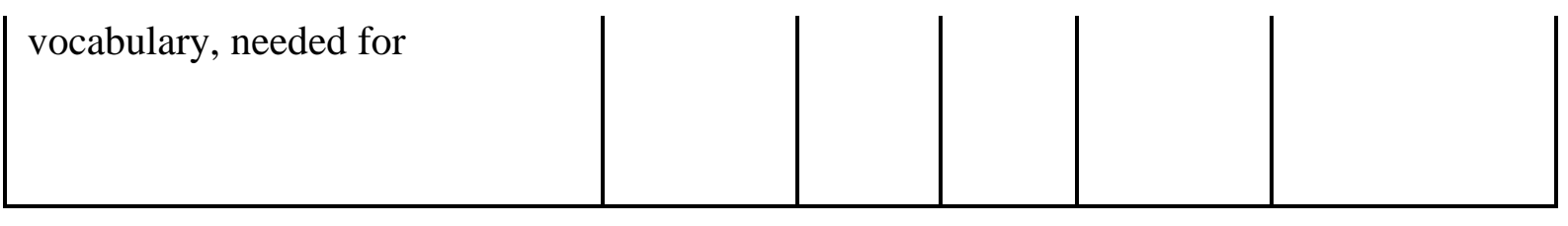

ro

\begin{tabular}{|c|c|c|c|c|}
\hline comprehension. & & & & \\
\hline $\begin{array}{l}\text { 4-Short stories help } \\
\text { students acquire } \\
\text { grammatical rules, which } \\
\text { in turn affects reading } \\
\text { comprehension. }\end{array}$ & $\begin{array}{l}14 \\
46.7 \%\end{array}$ & $\begin{array}{l}15 \\
50.0 \%\end{array}$ & & $\begin{array}{l}1 \\
3.3 \%\end{array}$ \\
\hline $\begin{array}{l}\text { 5-Using short stories as } \\
\text { supplementary materials } \\
\text { can motivate students } \\
\text { toward reading } \\
\text { comprehension. }\end{array}$ & $\begin{array}{l}15 \\
50.0 \%\end{array}$ & $\begin{array}{l}13 \\
43.3 \%\end{array}$ & $\begin{array}{l}1 \\
3.3 \%\end{array}$ & $\begin{array}{l}1 \\
3.3 \%\end{array}$ \\
\hline
\end{tabular}

Table (4.5) shows that about half (47\%) of responders strongly agreed that supporting texts with shapes, flashcard, and puppets can help students to overcome these difficulties about $(44 \%)$ of the responders agreed with this idea. Whereas $(4 \%)$ of them disagreed with the same point. (7\%) of the responders were not sure with supporting texts with pictures, shapes, flash card and puppets can help students to overcome these difficulties. Half (50\%) of the responders agreed that frequent training of teachers can help to overcome reading 
comprehension problems. More than one-third (37\%) of the participants strongly agreed with this idea, whereas $(7 \%)$ of responders strongly disagreed with this point, and the same number of respondents were not sure about this point. Half (50\%) of the responders strongly agreed on using short stories beside the main reading text can enhance students' vocabulary. Whereas more than one-third $(38 \%)$ of the responders strongly agreed with that point. Only a small number $(10 \%)$ of the responders strongly disagreed with this idea, whereas $(3.3 \%)$ were not sure with this point. Half $(50 \%)$ of the responders agreed that short stories help students to acquire grammatical rules. About half (47\%) of participants strongly agreed with this point, whereas $(3 \%)$ of the responders strongly disagreed this idea. Half $(50 \%)$ of the responders strongly agreed that using short stories as supplement materials can motivate students toward reading. (44\%) of the responders agreed with this point. Whereas $(4 \%)$ of the participants strongly disagreed with this idea. And the same number was not sure about using short stories as supplement material can motivate students toward reading.

Testing the Hypotheses

No doubt, the hypotheses of this research are very important. So, the researcher seeks hardly to make sure that the hypotheses are tested properly. Regarding the first hypothesis, 'There are some problems faced by Sudanese secondary school in reading comprehension skill'. Table (4.1) displayed that most Kenana secondary school students face problems in answering reading comprehension passages. So, more than two-third of teachers agreed that there are problems in teaching reading comprehension.

The second hypothesis, 'The main sources of these problems could be; students' lack of vocabulary, students' ignorance of reading comprehension skill, lack of teacher training courses and students' lack of motivation toward reading. The results showed that most of the respondents agreed that students lack vocabulary. They also had negative attitudes toward reading comprehension. As for the third hypothesis, 'Using short stories as supplementary 
materials to enhance students' motivation and vocabulary', table 4.3 showed that most of the teachers $(98.2 \%)$ agreed that short stories can enhance students' reading comprehension through increasing vocabulary and motivating them.

Summary of Findings

According to the results of the teachers' questionnaire, the study has revealed the following points;

1- Teaching reading comprehension in secondary school is a problem.

2- The study finds out the causes of reading comprehension problems are represented in the students and teachers.

3- In the teacher cases; lack of using teaching aids and lack of training courses for teachers are the main causes of reading problem.

4- Lack of motivation, vocabulary and grammar are the main causes of reading comprehension for students.

5- Large classes is the main cause of reading comprehension problems.

6- Using short stories as extra material can solve students' motivation, vocabulary and grammar problems.

Recommendations

Reading comprehension plays a vital role in teaching English language. So more emphasis should be given to the factors that affect reading comprehension passages. The present research attempts to offer some recommendations for syllabus designers and teachers so as to assist them in improving the reading comprehension process:

Teachers should motivate students to have more interest in reading materials in English language. 
Teachers should adopt modern teaching methods in teaching reading and neglect the traditional ones.

$\square$ Teachers should provide students with enough assignments and exercises after any reading comprehension passage to boost their comprehension.

$\square$ Teachers should encourage students to make extensive reading so as to improve their level of comprehension.

Syllabus designers should also design textbooks that pay more attention to develop learners' comprehension of reading texts. 


\section{References}

Alderson, J (1984). Reading in a ForeignLanguage. Encyclopedia of language. Cambridge Dechant \& Emerald. (1991) Understanding and Teaching ReadingDallas library. London Francoise, G. (2000). Developing Reading skills, Cambridge,Cambridge University.

Pamela, F and William, J (1986) Strategies of teaching readingking stone press Britain. 